\title{
Evaluation of Knowledge of Patients with Hemophilia Regarding Their Diseases and Treatment in Iran
}

\author{
Iran'daki Hemofili Hastalarının Hastalıkları ve Tedavileri Hakkında Bilgilerinin \\ Değerlendirilmesi
}

Mehran Karimi, Tahereh Zarei, Sezaneh Haghpanah, Zohreh Zahedi

Shiraz University of Medical Sciences, Hematology Research Center, Shiraz, Iran

To the Editor,

Hemophilia $A$ and $B$ are hereditary $X$-chromosomal recessive disorders affecting 1 in 5000 male births [1,2]. Hemophilia is classified as severe at F VIII / F IX $<1$ kIU L-1, moderate at 1-5 kIU $\mathrm{L}^{-1}$, and mild at $>5-25 \mathrm{kIU} \mathrm{L}^{-1}[3]$.

During the mid-1970s hemophilia care underwent substantial improvement to provide more optimal disease management for bleeding prevention strategies and education programs. This led to better educational strategies for disease management $[4,5]$.

Home therapy can be used to manage mild and moderate bleeding episodes and can help to achieve optimal treatment, resulting in decreased pain and hospital admissions for complications [6].

In this cross-sectional study, 30 patients with hemophilia $A$ and $B$ who were registered at the Hemophilia Center of Shiraz, Fars Province, southern Iran, were investigated between March and October of 2013. The data collection form consisted of two parts including demographic data and 22 specific questions regarding assessment of knowledge of the patients regarding the disease and treatment. In this latter section specific topics included appropriate treatment, disease transmission, physiotherapy application, management of bleeding, and the most common symptoms of bleeding.

The correct answer to questions had a sum of 1 to 4 points. Some of the questions had more than one correct answer.

Total knowledge scores were categorized into three grades: scores of 1-14 (poor knowledge), 15-29 (fair knowledge), and 30-41 (good knowledge).

This study was approved by the Ethics Committee of Shiraz University of Medical Sciences.
Data were analyzed by SPSS 17 using the Mann-Whitney U test and the Pearson correlation test, and $p<0.05$ was considered as statistically significant.

Demographic characteristics of the patients including disease severity and educational level are shown in Table 1.

Participants included 3 female patients and 27 male patients; 26 patients had hemophilia type $A$ and 4 patients had hemophilia type B.

The median age of the patients was $23.5 \pm 6.1$ years, ranging from 8 to 37 years old. Seven patients had a mild/moderate and 23 had a severe form of hemophilia.

Overall, the mean knowledge score of the patients was determined as $14.7 \pm 4.5$ (range: $4-26$ ). Considering the three levels of knowledge classification, all patients fell into the first category of poor knowledge (score of <30). There was no significant correlation between the knowledge of the patients and their ages $(p=0.094)$. The results also revealed no significant association between the knowledge of patients and disease severity $(p=0.446)$ or educational level ( $p>0.999)$.

There are limited studies that assess the knowledge level of individual patients regarding the management of hemophilia $[7,8,9]$. An important finding of this study was that patients' knowledge was not correlated with age, educational level, or disease severity.

Table 1. Demographic characteristics of the patients with hemophilia, including severity and educational level.

\begin{tabular}{|l|l|l|}
\hline Variables & $\begin{array}{l}\text { Median } \\
\text { (Interquartile Range) }\end{array}$ & p-value \\
\hline $\begin{array}{l}\text { Severity } \\
\text { Severe } \\
\text { Moderate/mild }\end{array}$ & $\begin{array}{l}15(5.50) \\
14(5)\end{array}$ & 0.446 \\
\hline $\begin{array}{l}\text { Education level } \\
\text { High school Diploma }\end{array}$ & $15(5.63)$ & $>0.999$ \\
Undergraduate Diploma & $15.5(11.13)$ & \\
\hline
\end{tabular}


Hemophilia associations should be recommended for educational programs for patients and caregivers. Hematologists and nongovernmental organizations can work together for lifelong educational programs. Finally, we recommend holding patient workshops twice a year as well as publishing simple books or brochures in each local language to improve the knowledge and therefore the quality of life of these patients.

Keywords: Knowledge, Hemophilia, Treatment, Disease

Anahtar Sözcükler: Bilgi, Hemofili, Tedavi, Hastalık

\section{Ethics}

Ethics Committee Approval: This study was approved by the Ethics Committee of Shiraz University of Medical Sciences.

\section{Authorship Contributions}

Concept: Mehran Karimi; Design: Mehran Karimi; Editing the Manuscript: Mehran Karimi; Data Collection or Processing: Zohreh Zahedi; Analysis or Interpretation: Sezaneh Haghpanah; Literature Search: Tahereh Zarei; Writing: Tahereh Zarei.

Conflict of Interest: The authors of this paper have no conflicts of interest, including specific financial interests, relationships, and/or affiliations relevant to the subject matter or materials included.

\section{References}

1. Stachnik J. Hemophilia: etiology, complications, and current options in management. Formulary 2010;45:218.

2. Lee CA, Berntorp EE, Hoots WK. Textbook of Hemophilia. New York, John Wiley \& Sons, 2011.

3. White GC 2nd, Rosendaal F, Aledort LM, Lusher JM, Rothschild C, Ingerslev J; Factor VIII and Factor IX Subcommittee. Definitions in hemophilia. Recommendation of the Scientific Subcommittee on Factor VIII and Factor IX of the Scientific and Standardization Committee of the International Society on Thrombosis and Haemostasis. Thromb Haemost $2001 ; 85: 560$.

4. Smith PS, Levine PH. The benefits of comprehensive care of hemophilia: a five-year study of outcomes. Am J Public Health 1984;74:616-617.

5. Soucie JM, Nuss R, Evatt B, Abdelhak A, Cowan L, Hill H, Kolakoski M, Wilber N. Mortality among males with hemophilia: relations with source of medical care. Blood 2000;96:437-442.

6. Teitel J, Barnard D, Israels S, Lillicrap D, Poon MC, Sek J. Home management of haemophilia. Haemophilia 2004;10:118-133.

7. Lindvall K, Colstrup L, Wollter IM, Klemenz G, Loogna K, Grönhaug S, Thykjaer $\mathrm{H}$. Compliance with treatment and understanding of own disease in patients with severe and moderate haemophilia. Haemophilia 2006;12:4751.

8. Nazzaro AM, Owens S, Hoots WK, Larson KL. Knowledge, attitudes, and behaviors of youths in the US hemophilia population: results of a national survey. Am J Public Health 2006;96:1618-1622.

9. Miller K, Guelcher C, Taylor A. Haemophilia A: patients' knowledge level of treatment and sources of treatment-related information. Haemophilia 2009;15:73-77.

\title{
Therapeutic Plasma Exchange Ameliorates Incompatible Crossmatches
}

\section{Çapraz Karşılaşıırma Uyumsuzluklarını Ortadan Kaldıran Tedavi Edici Plazma Değiş̧imi}

\author{
Mehmet Özen¹, Sinan Erkul2, Gülen Sezer Alptekin Erkul2, Özlem Genç3, Engin Akgül2, Ahmet Hakan Vural2 \\ ${ }_{1}^{1}$ Dumlupınar University Faculty of Medicine, Department of Hematology, Kütahya, Turkey \\ 2Dumlupınar University Faculty of Medicine, Department of Cardiac Surgery, Kütahya, Turkey \\ ${ }^{3}$ Dumlupınar University Faculty of Medicine, Blood Bank Unit, Kütahya, Turkey
}

\section{To the Editor,}

Red blood cell (RBC) transfusion is a risk factor for mortality and morbidity in coronary artery bypass graft (CABG) surgery, and transfusion-related adverse effects may be catastrophic in these patients $[1,2,3,4]$. Unfortunately, there are no recommendations for these patients regarding how to proceed in the case of incompatible crossmatch tests against donors' blood. To our knowledge, there is no report about the role of therapeutic plasma exchange (TPE) in resolving incompatible crossmatches.

A 73-year-old man was admitted to our hospital because of chest pain. He had no previous medical history of coronary artery disease or any other diseases, including hemolytic disease and recent infection. In addition, he used no medication and had not received blood transfusions. After coronary angiography, a 